This item was submitted to Loughborough's Research Repository by the author.

Items in Figshare are protected by copyright, with all rights reserved, unless otherwise indicated.

\title{
Fresh driver for economic growth: fracking the UK nation
}

PLEASE CITE THE PUBLISHED VERSION

http://dx.doi.org/10.1108/IJESM-10-2014-0004

\section{PUBLISHER}

(c) Emerald

\section{VERSION}

AM (Accepted Manuscript)

\section{PUBLISHER STATEMENT}

This work is made available according to the conditions of the Creative Commons Attribution-NonCommercialNoDerivatives 4.0 International (CC BY-NC-ND 4.0) licence. Full details of this licence are available at: https://creativecommons.org/licenses/by-nc-nd/4.0/

\section{LICENCE}

CC BY-NC-ND 4.0

\section{REPOSITORY RECORD}

Ochieng, Edward G., Andrew D.F. Price, Charles O. Egbu, Ximing Ruan, and Tarila Zuofa. 2019. "Fresh Driver for Economic Growth: Fracking the UK Nation". figshare. https://hdl.handle.net/2134/21332. 


\section{Fresh Driver for Economic Growth: Fracking the UK Nation}

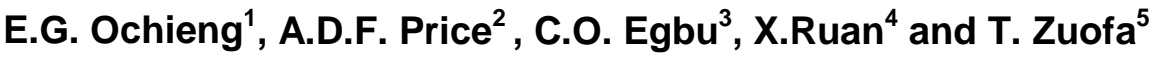

${ }^{1}$ School of the Built Environment, Liverpool John Moores University, Byrom Street, Liverpool, L3 $3 A F$

${ }^{2}$ Department of Civil and Building Engineering, Loughborough University, Leicestershire, UK, LE11 3TU

${ }^{3}$ School of the Built Environment and Architecture, London South Bank University, London, England,UK.

${ }^{4}$ Bristol Business School, University of the West of England, Frenchay Campus, Bristol, $B S 161 Q Y$

${ }^{5}$ Department of Business Information Management and Operations, University of Westminster, Marylebone, London, UK, NW1 5LS

Dr. Edward Ochieng: BSc (Hons), MSc, PGCertHELT, PhD, FAPM, FHEA

Current Post: Senior Lecturer in Project Management

Phone: +44 (0) 151231 2859; Fax: +44 (0) 1512312859

Email: e.g.ochieng@ljmu.ac.uk

Prof. Andrew Price: BSc, PhD, FCIOB, FICE, CEng

Current Post: Professor of Project Management, Director of Postgraduate Studies, CoAcademic Director of HaCIRIC (Loughborough University).

Phone: (01509) 222627

Email: a.d.f.price@lboro.ac.uk

Prof. Charles Egbu: BSc (Hons), PhD, APDRAS, FAPM

Current Post: Dean

Tel: $+44(0) 2078158302$

Email: egbuc@Isbu.ac.uk

Dr. Ximing Ruan: MBA, PGCertHELT, PhD, FAMP

Current Post: Senior Lecturer in Strategy and Operations Management

Tel: +44 (0)1224 263811

Email: Ximing.ruan@uwe.ac.uk

Dr. Tarila Zuofa: BSc, MSc, PhD

Current Post: Lecturer in Project Management

Tel: +44 7521023300

Email: T.Zuofa@westminister.ac.uk 


\section{Abstract}

The recent commitment to shale gas exploration in the United Kingdom (UK) through fracking has given rise to well publicised economic benefits and environmental concerns. There is potential for shale gas exploration in different parts of the United Kingdom over the next couple of decades. As argued in this study, if it does, it would transform the energy market and provide long term energy security at affordable cost. The aim of this study was therefore to examine UK shale gas viability. Interviews with senior practitioners and local communities were recorded, transcribed and entered into qualitative research software Nvivo. Validity and reliability were achieved by first assessing the plausibility in terms of already existing knowledge on some of the economic and environmental issues raised by participants. Findings from this study suggest that environmental, health and safety risks can be managed effectively provided operational best practices are implemented and monitored by the health and safety executive, department of energy, climate change and the mineral planning authorities. Participants further suggested that the integration of shale gas technology will protect consumers against rising energy prices and ensure that government does not get exposed to long-term geopolitical risks.

Keywords: Fracking, United Kingdom, Geopolitics, UK energy sector, UK economic growth

\section{I ntroduction}

The International Energy Agency (IEA) established that fossil fuels are the world's leading source of energy, accounting for approximately 81 per cent of world primary energy use (IEA, 2011). However, with dwindling conventional reserves and higher demand for energy, there is growing desire to exploit unconventional energy sources (UNEP 2011). Hydraulic fracturing commonly referred to as "fracking" is a gas extraction technique used for tapping unconventional oil and gas reserves that are otherwise inaccessible in low permeable rocks. This is referred as unconventional gas (UG) production. Statistics from IEA indicate that there is enough UG globally to increase the global energy resource base to about 25 per cent in 2035(IEA, 2011, 2012). However, with the geographic distribution of UG differing from that of conventional fossil energy resources, Milosevic and Markovic (2012) argued that it has brought about revolutionary changes to the dynamics of the global geopolitics within the energy sector. These changes have triggered heightened economic interests as well as strong opposition. For this and other reasons those countries largely reliant on foreign imports to meet their energy supply may consider looking at local UG as one strategy for 
decreasing their external dependency. In many ways, the development of UG would enable these categories of countries achieve greater energy independence, making the exploitation of UG reserves highly attractive to some governments.

The UK is in the midst of a dash for gas and inland shale may hold enough untapped gas to meet the UK's needs for twenty-five years (DECC 2013). Negotiations between the government and the UK Onshore Operators Group have resulted in a new "industry charter" (Pasty et al. 2013). Its primary provisions mean that if new gas is discovered and put into production, local communities could receive financial benefits: $£ 100 \mathrm{k}$ for every well that is fracked as part of exploration; and one per cent of revenues if wells prove to be commercially feasible (Harris 2013; Richards and Fell 2013). As the UK imports almost half of its fossil fuels, future cost and energy security are of considerable concern and any plentiful domestic gas sources need to be fully explored (Hunter 2013). The Institute of Directors (2013) presented a scenario where UK shale gas production attracts investment of $£ 3.7$ billion per year and supports up to 74,000 jobs, often focused in regions with currently high unemployment and in sectors such as manufacturing. It also has the potential to contribute significant tax revenues. The Secretary of State (2013) repeated the loD figures, and even proposed hypothecation of shale gas revenues, a policy normally opposed by Chancellors (DECC 2013). Recently, former BP chairman Lord Browne stated that "we have an idea of the UK's potential for shale, what we now need is to figure out how much we can produce economically and how fast, which means wells need to be drilled and need to be fracked-there is no other way to do it" (Harvey 2013). According to Lord Browne, it is in the national interest of the UK to do something that is good for the UK and fits into the bigger picture of combating climate change globally (Harvey 2013).

In a recent visit to a Lincolnshire site in UK, the Prime Minister reaffirmed The Institute of Directors figures and suggested that the English local authorities would receive all the business rates collected from shale gas schemes-rather than the usual 50 per cent. The UK Prime Minister noted that "fracking was already flooring energy prices in the US, and could be a fresh driver of UK growth" (BBC 2014). The Prime Minister further asserted that there is no doubt that when it comes to re-shoring in the US, one of the most significant factors has been the introduction of shale gas, with billions of dollars of energy cost-savings predicted over the decade. The huge challenge for energy policy makers in the UK is how they make fracking a success. For instance, Government advisers on the Committee on Climate Change, as well as the UK Energy Secretary casted doubt on whether utilising shale gas 
reserves in the UK will lead to lower energy prices (BBC 2014). From the reviewed literature, it seems that relying heavily on gas for future electricity supply will leave households vulnerable to higher bills in the long run as the price of gas on the international market is volatile. Secondly, the UK will not benefit from sustainable lower prices unless the rest of Europe decides to back shale gas too, as Europe has a gas grid that allows gas to be traded to the highest bidder. The aim of this study was therefore to examine the UK shale gas achievability. The next section reviews policy issues, relevant literature on UK energy sector, fracking perspective in the UK and environment considerations for fracking.

\section{Policy context}

According to Davis (2012), hydraulic fracturing has provided a major technological boost to industry efforts to obtain greater amounts of natural gas from unconventional sources. For instance in the United States, the recent upsurge has been prompted by the discovery of large new reserves of coal or shale bound gas and by technological improvements such as combining fracking with horizontal drilling techniques adopted from deep water oil and gas wells operating in the Gulf of Mexico (American Petroleum Institute, 2010; U.S. Energy Information Administration, 2011). A study by IHS Cambridge Energy Research Associates showed that shale gas released from unconventional sources amounted to 1 per cent of gas supplies in 2000. In 2010 the figure increased to 20 per cent and is expected to reach 50 per cent by the year 2035 (IHS Global Insight, 2010). As suggested by Brown and Krupnick (2010), natural gas now represents roughly a quarter of total energy consumption in the US, a percentage that is likely to surge in view of the problems associated with the development and use of other fuel such as coal.

From a UK viewpoint, it is worth highlighting that oil and gas reserves are declining but it is vital the UK have safe, secure and future-proof supplies of energy that will be available to all. Over the past few decades, the UK has experienced string energy security from a combination of its liberalised energy markets, firm regulation and extensive North Sea resources (DECC 2012). Whilst, the UK's energy market has been resilient to energy security challenges, it now faces ongoing geopolitical risks, severe weather risks, technical failure risks, terrorist attacks risks, industrial action risks, community risks and market risks (DECC 2012). In addition, the UK energy market faces a great deal of change as existing infrastructure closes, domestic fossil fuel reserves decline and the system adapts to meet low carbon objectives. The above risks can be mitigated but it is impossible to avoid them entirely. In years ahead, these risks will create new challenges for the UK energy market. To 
ensure the UK's energy system has adequate capacity and is diverse, Government actions will be based on (DECC 2012; Ochieng et al. 2014):

- Reforming the electricity market;

- Removing barriers to competitive markets;

- Preparing for energy emergencies;

- Increasing energy efficiency;

- Working internationally;

- Maximising cost-effective recovery of UK resources;

- Maintaining reliable networks; and

- Reducing carbon from UK energy supplies.

It is worth noting that the UK Government and the Devolved Administrators have a collective interest in ensuring security across the United Kingdom. The UK Government works closely will all Devolved Administrators, in line with their respective roles and responsibilities as highlighted in the devolution settlements, drawing on local knowledge and expertise, to ensure a safe and secure energy supply. As suggested by DECC (2012), Great Britain's energy policy is largely a reserved matter and the responsibility of the UK Government. However, due to the uncertainty and complexities of the devolution settlements this is not always clear-cut and some of the areas examined in the energy security report will always overlap with the competencies of the Welsh and Scottish Governments. Government energy security will be based on competitive energy markets combined with effective regulation to deliver diversity of supply and robust infrastructure for consumers (DECC 2012). Beyond energy security concerns, there are economic and political advances to support cost effective recovery of UK resources (i.e. shale gas).

\section{UK Energy sector: Challenges and Opportunities}

Over the past four years, energy companies have invested over $£ 43$ billion in the UK (OGER 2009). In 2009 and 2010, the oil and gas sector invested more than $£ 5$ billion in the UK economy, and spent $£ 13$ billion on exploration, developments and operations. The sector also contributed $£ 9.4$ billion to the Exchequer in corporate taxes, which is an increase of 45 per cent over the previous two years, thus adding to the $£ 276$ billion invested since the 1960s (OGER 2009). It has provided employment for approximately 450,000 employees, many highly skilled, throughout the country (Ernst and Young 2011; OGER 2010; 2012). The oil and gas sector has also developed a world class supply chain in the UK, especially in Scotland, which has grown rapidly and now exports goods and services worth in excess of 
$£ 5$ billion per year to more than 100 nations (OGER 2010; 2012). Although the recent financial crisis has put a temporary constraint on energy demand, growth in energy is beginning to resume and in the years ahead there will be an increased need for gas, predominantly for electricity generation, where it will gradually replace old coal fired power and provide back-up arising from the intermittency in wind power (Kjarstad and Johnsson 2009; Mohr and Evans 2010; OGER, 2010). Investment in United Kingdom Continental Shelf (UKCS) increased from $£ 8.4$ billion in 2011 to $£ 11.4$ billion in 2013 and companies have just under $£ 100$ billion of capital investment in their current business plan (OGER 2013). The UK government will have to invest a total of $£ 200$ billion by 2020 to decarbonise its power industry, thus doubling the rate of investment over the last 10 years (OGER 2012). However, every credible scenario indicates further growth in demand for oil and gas over the next 20 years and providing around 70 per cent of UK energy in 2020 (OGER 2012). The rise in energy demand and security has created a significant need to invest in shale gas technology (Aleklett et al. 2010; Erdos 2012; Nakhle 2007).

It has been suggested that due to steadily rising demand, putting off investment is not feasible (Accenture 2012; Asche et al. 2012; Aleklett et al. 2010; Ochieng et al. 2014; Nakhle 2007). In recent years, energy organisations, as a whole, have not been growing through investment. A majority of energy organisations have investment ratios of less than one, which means they have been investing at a lower rate than required to maintain the asset base (Accenture 2012). It has been conclusively shown that ratios will need to rise above one to meet forecast growth in demand (Accenture, 2012). Although energy efficiency has an important role to play, unparalleled levels of reserves will be required over the next two decades and the UK Government will have to make the most of its indigenous oil and gas resources (OGER 2012; 2013). The challenge is to capitalise on existing strengths, address challenges and deliver actions to ensure maximum resource recovery is cost effective. According to Harvey (2013), the UK's energy sector has not faced such extraordinary combination of dire problems since the crisis of the 1970s. Policy intercession by Government will be vital to tackle multiple looming difficulties and encourage the massive investment needed from the private sector. Key to the UK Government's thinking on energy policy will be to set out a framework for increasing energy generation, moderating fuel prices for consumers and incorporating shale gas technology into the energy mix (Harvey 2013). The energy sector will remain one of UK's outstanding economic sectors for many years to come (Mckenna et al. 2006; Ochieng et al. 2014; OGER 2013; 2012).

\section{Universal fracking background}


It is worth noting that fracking can be used to get not just gas out of the rock, but oil. Hence, the global impact of shale gas oil technology could transform the global energy markets over the next couple of decades, resulting in higher global GDP, changing geopolitics, lower gas and oil prices and shifting business models for oil and gas companies (PwC 2013). For instance, it has been argued that lower oil prices due to increased shale oil production could have a major impact on the future evolution of the global economy by allowing more production at the same cost. PwC (2013) showed that these effects could build up steadily as shale technology rolls out across the world to produce an estimated increase in GDP of around 2.3 per cent to 3.7 per cent in 2035 . This would be roughly identical to adding an economy the size of the UK to total world GDP in that year. The economic benefits, of oil and gas price reductions will vary significantly by country. As suggested by PwC (2013), large net oil importers such as Japan and India may see their GDP boosted around 4 per cent by 2035, whilst the US, China, Germany and the UK might gain by around 2 per cent to 5 per cent by 2035. Major oil exporters such as the Middle East and Russia could be losers in the long term unless they start to introduce their own shale oil resources on a large scale. Impacts on GDP by country is summarised below:

Table 1: Estimated Impact on GDP in 2035 due to 25 per cent to 40 per cent cut in global oil prices

\begin{tabular}{|c|c|}
\hline Economy & $\begin{array}{c}\text { Estimated impact on level of GDP in 2035 } \\
\text { (\% change vs baseline EIA oil price scenario) }\end{array}$ \\
\hline India & 4.6 to 7.3 \\
\hline Japan & 4.2 to 6.8 \\
\hline US & 2.9 to 4.7 \\
\hline Germany & 2.5 to 4.7 \\
\hline UK & 2.0 to 3.3 \\
\hline China & 1.9 to 3.0 \\
\hline Brazil & 1.3 to 2.0 \\
\hline Russia & -1.2 to -1.8 \\
\hline World & 2.3 to 3.7 \\
\hline
\end{tabular}

Source: PwC 2013

According to the Royal Society (2012), shale gas could increase global natural gas resources by approximately 40 per cent. The US Information Administration (EIA) estimated the global technically recoverable resources of natural gas to be approximately 16,000 trillion cubic feet (tcf) (EIA 2011). EIA (2011) further noted that the total volume of technically recoverable shale gas globally to be 6,622 tcf. In Europe, Poland and France are two of the 
most promising shale gas nations with 187 tcf and 180 tcf of recoverable resources respectively. China has 1,275 tcf, USA has approximately 862 tcf. Sweden, Norway and Ukraine also possess large technically recoverable resources.

From the reviewed literature, it has been established that the development of shale gas in North America has revolutionised the gas-market outlook. In its annual world energy outlook, IEA (2009) noted that unconventional gas had "changed the game" in North America and elsewhere. For instance, in 2011 unparalleled levels of domestic natural gas reduced net imports of natural gas by a quarter, with several applications being made to the US Department of Energy for authorisation to export LNG. According to IEA (2011), US is expected to be nearly self-sufficient in energy by 2035. Interestingly, IEA (2011) suggested that the global technically recoverable resource of shale gas is likely to be over 97 trillion cubic meters, which is equivalent to around 23 per cent of estimated remaining recoverable resources of conventional gas, but with large variation between studies (McGlade et al. 2012). EIA (2011) showed that natural gas will overtake coal by 2030, increasing to 25 per cent of the global energy mix by 2035 .

\section{Fracking perspective in the UK and policy issues}

Over the past century, the UK has experienced reduced domestic production from the North Sea and an increased reliance of natural gas imports (Royal Academy 2012). New pipelines from Netherlands and Norway and liquefied natural gas make up the difference. In their assessment in 2012, the House of Commons Energy and Climate Change Committee argued that domestic resources could reduce the UK's dependence on imports, but the effect on energy security may be unlikely to be colossal (HoC 2011). The Committee further noted that if a significant amount of shale gas enters the UK gas market (whether from domestic or foreign sources), it will probably deject investment in more expensive, lower carbon emission renewables (HoC 2011). Data from DECC (2013) indicate that UK has experience of hydraulic fracturing and directional for non-shale gas. As evidenced from the reviewed literature, the first UK well to encounter shale gas (accidently) was drilled in West Sussex in 1875 (Netherfield), and in 1895 the nearby Heathfield well produced enough gas to light the local railway station until well into the $20^{\text {th }}$ century (DECC 2013). Advances in directional drilling have led to the development of the Wytch Farm field onshore and offshore Dorset. British Gas discovered the Wytch Farm field but it is now been operated by Perenco. The field is responsible for a number of UK onshore oil production (DECC 2013; 2013). 
Results of work by Richards et al. (2013) suggest that UK production of natural gas in 2012 was the lowest since 1985. According to Richards et al. (2013), the UK has been a net importer of gas since 2004, with historically high imports in 2011. In that year, for the first time since large scale gas extraction began, UK imports exceeded production (DECC 2013). Industry interest in shale gas extraction in the UK can be summarised as follows (Royal Academy 2012):

- England: Three potential shale gas exploration well sites have been identified by Cuadrilla in Lancashire. The first and second wells were drilled in 2010 at Preese Hall and Grange Hill Farm; and the third near the village of Banks in August 2011. Other sites identified include: Balcombe, Elswick, Westby, Banks, Clifton, Roseacre Wood owned by Cuadrilla, Barton Moss owned by IGas and Cheshire owned by Dart Energy. Three other possible sites have been identified in the Mendip Hills by Methane and Eden Energy. One site has been identified in Woodnesborough, Kent, by Coastal Oil and Gas Limited.

- Wales: Three sites have been discovered by Coastal and Gas Limited. Planning permission were granted for sites at Neath and Maesteg where wells will be deepened to obtain geological samples.

- Scotland: Although potential shale formations have been discovered in Scotland, to date the Scottish Government has already tightened planning rules to make it harder for fracking to take place. Interestingly, a report published by Department of Energy and Climate Change (DECC) showed exploration in Scotland formed a significant part of its long term plans.

- Northern Ireland: Tamboran Resources has an interest to extract shale gas in an area that extends across the border between Northern Ireland and the Republic of Ireland.

In their recent reports, Department of Energy and Climate Change (2013; 2013) noted that UK has a goal-setting approach to exploration that requires operators to ensure and demonstrate to regulators that the risks of an incident to oil and gas operations are reduced to 'as low as reasonably practicable'. This allows operators to move beyond minimum standards in continuous effort for improvement. According to White et al. (2014), a UK Petroleum Exploration and Development licence (PEDL) allows operators to pursue a 
number of exploration activities, including exploration and development of unconventional gas, subject to necessary drilling/development consents and planning permission. To date, PEDLs allow a company only exclusivity in an area to search for, bore for and get hydrocarbons. They are separate from all other permissions, including:

- Planning permission;

- Any need to gain access rights from landowners;

- Environmental permits, including for mining waste, from Environmental Agencies;

- Health and safety regulations and permits from the HSE; and

- Consent to drill and frack, from DECC (White et al. 2014).

As a result, the terms of the PEDL licences require DECC's approval for the choice of operator. One of the issues DECC checks before endorsing an operator is coverage of relevant insurance (White et al. 2014). Evidence shows that UK has, alongside Norway, one of the most stringent offshore drilling safety regimes in the World (White el al. 2014). According to White et al. 2014, HSE monitors shale gas operations from a well integrity and site safety perspective. They oversee that safe working practices are adopted by onshore operators as required under the Health and Safety Work Act 1974, and regulations made under the Act. These specifically are:

- The borehole site and operations regulations 1995 (BSOR) applies to shale gas operations; and

- The offshore installations and wells (Design and Construction) regulations 1996 (DCR) apply to all wells drilled with a view to the extraction of petroleum regardless of whether they are onshore or offshore.

There are a number of common key issues which are relevant throughout the planning process (Ruddiman et al., 2013):

- Pre-application engagement and consultation: an engagement and consultation strategy should be incorporated at the outset and should be subjected to critical analysis before it is deployed;

- Environmental impact assessment: the nature of the environmental data to be integrated as part of the planning applications should be wide ranging and may include the following data: geological information, ecology, water, transportation, flood risk, 
archaeological, contamination and landscape character. Given that there are several variables to the fracking process each of these will need to be assented separately with the exception of abandonment which will be covered by the full development and production agreement;

- Government support: as evidenced from the reviewed literature, the Government is supportive of fracking. This support is unsurprising given the incentives it brings in being able to produce low cost gas in the UK whilst at the same time condensing greenhouse gas emissions;

- Legal challenge and risk: the potential of legal challenge reinforces the importance of executing an effective pre-application engagement and consultation in order to try to alleviate any concerns that local communities and relevant bodies may have about the proposed development;

- Planning performance agreements (PPA): as found in the literature, it is compulsory to use a PPA, although as with any complex planning application serious consideration should be given to the use of one;

- Interaction with other government bodies: the role of the planning system should consider whether the development and use of the land is satisfactory. This defined role is different from other regulatory regimes, for example the prerequisite for an Environmental Permit.

More complex extraction techniques and new technologies have given rise to new risks and complexity, i.e. fracking. Fracking itself uses a technique whereby deep wells are drilled into underground shale deposits, and pumped with water, laced with sand and chemical agentswhich fractures the rocks, and releases natural gas (along with lots of contaminated water (H2O), often in the form of residual (Harris 2013).

\section{Environmental considerations for fracking}

The Royal Society and Royal Academy of Engineering (2012) found that the health, safety and environmental risks associated with fracking can be managed effectively in the UK, by implementing and enforcing best technological advances, and novel operational and project management practices, however, they made several recommendations including calling for more research on the carbon footprint of shale gas extraction. Whilst joining in with the debate, Richard et al. (2013) argued that generating electricity from natural gas is relatively 
clean in comparison to coal fired generation. According to Pearce (2013) more gas could help bridge the gap to cleaner renewables or more nuclear generation. For instance, US carbon emissions have fallen by 9 per cent since 2005, reversing a strong upward trend, and the US Environmental Protection Agency (EPA) has credited almost half of the reduction to shale gas use (Brooks 2013).

From a UK standpoint, recent evidence shows that the emissions benefits of domestic production over importing liquid natural gas (LNG), the potential of shale gas as a transport fuel and avoided emissions through supporting energy efficient manufacturing in the UK (IOD 2013). However, it has inconclusively been shown that cheap gas may deflect investment from more expensive (up-front) options such as renewables and nuclear, weakening the case for reducing reliance on fossil fuels. Recent results from the Broderick et al. (2011) confirmed that emissions from a fully developed UK shale gas industry would likely be very substantial in their own right. If the UK Government is to respect its obligations under both the Copenhagen Accord and Low Carbon Transition Plan, shale gas offers no meaningful potential as even a transition fuel.

Results from Broderick et al. (2011) further suggested that excessive water use for fracking has a particular problem given that water resources in many parts of the UK are already under pressure. In its response to 2011 Energy and Climate Change Committee inquiry, the Government argued that adverse effects on water resources as a result of possible expansion of the shale gas industry in the UK are not expected (White et al. 2013). As observed from the reviewed literature (White et al. 2013), any operator will need a licence to abstract water from the Environment Agency who will assess existing abstraction levels and licences. With regards to seismic risks, operators will be required to:

- Conduct a prior review of data on seismic risks and the existence of faults;

- Submit to DECC a frack framework showing how many seismic risks are to be mitigated;

- Carry out seismic monitoring before, during and after the frack; and

- Implement a "traffic light" system which will be used to identify unusual seismic activity requiring reassessment, or halting, of operations (White et al. 2013)

From the above analysis, the overall conclusion is that environmental risk assessment should address risks across the lifecycle of shale gas operations: exploration, appraisal, development and production, decommissioning, restoration and aftercare. It is also important 
to incorporate the local community throughout the life cycle. Many of the recommendations discussed above are already being adopted, and current guidelines are austere enough to protect the community and environment. The next section details the research method and a symposium of findings drawn from the twenty-interviews. This is followed by a conclusion and recommendations.

\section{Method}

Given the aim of the research, it was acknowledged that views of local communities, senior practitioners and policy makers in the UK energy sector were necessary. This allowed questions evoked from the initial research to be answered and contribute additional information to give a better understanding as to how fracking would contribute to the United Kingdom's energy balance. The use of a qualitative method was deemed to be the most appropriate research strategy to employ. The use of a quantitative approach was considered unsuitable as there was no hypothesis to commend or reject. Due to the complex nature of fracking and proposed U.K. Government policies, it was imperative to pick an evidence based research method. This study therefore focused on evoking further, more current information from participants and to gauge their opinions on questions of an explorative nature. A statistical hypothetical approach was not suitable for this type of data as the data was in the form of different senior practitioner's views and interpretations. With qualitative method, it was easier to gain a better understanding of Government energy policies and fracking life cycle.

A qualitative method of data collection was adopted by means of interviews. The interviews were set in structured format, with predetermined questions with the same wording and order, so that the same circumstances would apply for each participant. The interview questions were cautiously selected in an attempt to prevent any preconceived bias. It was assumed by Nachmias and Nachmias (1996) that the interviewees would have a sufficiently common vocabulary, so the constructed questions would have the same meaning for each of them and that it would be possible to phrase the questions in a format that is meaningful to each participant. Through using interviews it was easier to examine why the government is turning into shale gas technology.

The open ended interview questions allowed additional information to be gathered and further reasoning behind responses to be explored, this allowed for a better understanding behind the participants thinking. As previously mentioned views and perceptions of local 
communities, senior practitioners, and energy policy makers in the energy sector were required to answer questions evoked from the initial research and to gauge a fuller picture of fracking. The senior practitioners and energy policy makers were carefully chosen, to accurately represent the energy sector. The researchers attended a large national energy forum in Aberdeen (UK). This allowed the researchers to network with a range of professions across the spectrums who were involved in the supply chain of energy. This meant the most appropriate candidates for interview were selected at the event and it acted as a means of increasing the response rate through establishing the initial face to face contact. After the participants were then chosen and had agreed to participate in the interviews they were handed a hard copy of the finalised interview questions to review, and to allow them to air any queries they had in relation to the questions. Among the criteria used to identify leading senior practitioners were their abilities to manage energy projects and familiarity with fracking. A preliminary pilot study was carried out with the practitioners so as to assess clarity of questions. All twenty-five interviews were recorded to allow for ease of reference and to produce accurate transcripts. Table 2, presents the list of the interview participants selected as well as their background, their level of experience, and the types of organisations for which they belong.

Table 2: Selection of professionals interviewed

\begin{tabular}{|c|c|c|c|}
\hline Participants & $\begin{array}{l}\text { Number of } \\
\text { participants }\end{array}$ & Years of experience & Organisation \\
\hline $\begin{array}{l}\text { Senior oil and gas project } \\
\text { managers }\end{array}$ & $\begin{array}{c}\text { (5) } \\
A, E, D, J, Y\end{array}$ & $10-20$ & Energy \\
\hline Local communities from & $\stackrel{\text { (5) }}{B, C, F, G, H}$ & & $\begin{array}{l}\text { UK regions: Lancashire, } \\
\text { Grange Hill Farm, } \\
\text { Balcombe, Elswick and } \\
\text { Westby }\end{array}$ \\
\hline $\begin{array}{l}\text { Offshore development } \\
\text { managers }\end{array}$ & $\begin{array}{c}\mathbf{( 5 )} \\
\mathrm{I}, \mathrm{K}, \mathrm{L}, \mathrm{M}, \mathrm{N}\end{array}$ & $10-20$ & Energy \\
\hline Offshore head directors & $\begin{array}{c}\text { (5) } \\
P, Q, R, S, T\end{array}$ & $10-20$ & Energy \\
\hline $\begin{array}{l}\text { Senior Government policy } \\
\text { makers }\end{array}$ & $\mathrm{O}, \mathrm{U}, \mathrm{V}) \mathrm{W}, \mathrm{W}$ & $10-20$ & $\begin{array}{l}\text { Department of Energy and } \\
\text { Climate Change (UK) }\end{array}$ \\
\hline
\end{tabular}

For the purposes of confidentiality, the participant's names and the names of their organisations have been changed. These professionals were selected because of their vast knowledge of energy policy and their involvement in fracking in the UK. A "funnel" technique was adopted for the structure of the interviews, which meant more general questions were asked at the start to break the ice, which were easier to answer, followed by more specific questions which required more thought in relation to carbon emissions and geopolitics. The 
potential barriers, impact and drivers for fracking were examined in depth to understand the economic benefits and environmental concerns.

A copious amount of data was produced from the interviews, which needed to be analysed. It was important to choose the most adequate method for data analysis so the information could be interpreted efficiently and effectively. An inductive approach was utilised. According to Braun and Clarke (2006) this is where the researcher will try to identify commonality and report themes within the collated data. Boyatzis (1998) describes these themes as a pattern within the information that at a minimum will describe and categorises the observations and at a maximum will deduce aspects of the phenomenon. For this thematic analysis it was important to identify a limited amount of themes that would adequately reflect the documented data. Grbich (2007) concluded that it was a method of reducing data into meaningful categorises. Boyatatzis (1998) breaks thematic analysis down further into the phases of seeing (recognising a moment), encoding (seeing it as something) and interpretation.

It was also important that the researchers carried out the interviews themselves in order to familiarise themselves with the data at an early stage, as the first step of analysing qualitative data according to Braun and Clarke (2006). Each transcript was then individually broken down into various initial codes, $1^{\text {st }}, 2^{\text {nd }}$ and $3^{\text {rd }}$ level coding. These codes were then analysed for commonality and examined for themes. These themes were then revisited and allocated names, by the end of this stage Braun and Clarke (2006) conclude that the researcher should be able to define what the themes are and what they are not. This method of analysing the qualitative data was implemented once the interview transcripts were completed. A computer assisted qualitative data analysis software (CAQDAS) in the form of Nvivo was used. This allowed the data to be coded efficiently and thus reduced the time period needed to analyse the copious amount of data collected. The verification took place after the interpretation of data analysis. This involved presenting the findings to the main participants. The philosophical consideration of this research can be viewed from three broad perspectives. The first perspective was linked to the importance of alternative energy. The second perspective was linked to exploring key drivers of fracking. The third was linked to examining environmental concerns.

\section{Findings}


The findings are presented below under four main themes drawn from the analysis. Where appropriate, descriptive quotes drawn from the interview transcripts have been used to express the views of the participants.

\subsection{Theme 1: Fracking environmental effects}

In this particular theme, all twenty-five participants noted that the government should proceed with fracking. This was further explored with Participant $A$, who suggested that:

"Shale gas from fracking should be encouraged as part of UK's energy mix. According to Participant $(A)$ there is more evidence that operations can be delivered safely"

Participant E pointed out that:

"Environmental impacts are acceptable and that monitoring, reporting and mitigation strategies are comprehensive and effective".

Participant $Y$ further noted that:

"If managed and monitored well, fracking for shale gas has less environmental impacts from induced seismicity, water contamination, degradation of landscape and the release of fugitive emissions of methane."

All the participants were supportive of robust regulations. For instance, the participants suggested that Environmental Risk Assessment to be mandatory throughout the life cycle of fracking. A number of trepidations over fracking in the UK are a result of data from the United States. As evidenced from the reviewed literature (Armour 2014; Boudet et al. 2014; Martin et al. 2014; Smith and Ferguson 2013), studies in the US are largely focused in rural areas, where there is a small local population. Fracking locations in the UK are different because the population is denser, and the proposed sites are near to villages and towns. It was also emphasised by the participants that there have been mixed findings with some suggesting that energy bills will show a similar decline to those in the US, others suggesting that fracking causes earthquakes. However, differences in mineral rights and stringent regulations in the UK would not prohibit a similar situation occurring. Participants acknowledged that they don't know how much gas there is and how much it will cost to extract. Participant D suggested that it is likely to cost more than the US and that with the current gas supplies running out, the government will be subject to international market prices. 
With regards to earthquakes, a recent study led by Durham University and entitled "Induced Seismicity and the Hydraulic Fracturing of Low Permeability Sedimentary Rocks" found almost all of the resultant seismic activity was on such a small scale that only geoscientists would be able to detect it. It was conclusively found that the size and number of felt earthquakes caused by fracking is minimal compared to other manmade triggers such as mining, geothermal activity or reservoir water storage (Davies 2013). Participant J stated that there still remains limited indulgence about the commercial viability of shale gas in the UK. According to participant J, the Government's gas strategy needs to clearly highlight the contribution that fracking could make and how its environmental impacts will be mitigated. As established in the reviewed literature, the environmental, health and safety risks can be managed effectively, provided operational best practices are integrated and reinforced through robust regulation (Richard et al. 2013; White et al. 2014).

\subsection{Theme 2: Economic implications}

Up until now, much attention in the debate has focused on the potential negative local impacts. Despite lack of documented evidence, participants suggested that:

- The Government has played a key role in making shale gas exploration in the UK, the only country in Europe other than Poland, a reality. The five policy makers involved in this study confirmed that local communities who participate in shale development will receive millions of pounds in tax break. The results of this study provide independent empirical support for some of the recommendations made by the UK Prime Minister (BBC 2014);

- Fracking will unlock massive new supplies of oil and cleaning burning natural gas from dense deposits of shale-supplies that will increase UK energy security and enhance the country's ability to generate electricity, heat homes and power vehicles for generations to come. In terms of energy security, because the North Sea gas supplies are forecast to drop, shale energy is unlikely to maximise UK gas production or make the UK fully self-sufficient in gas;

- Fracking will lead to a shift in global competitiveness for the UK by unlocking new production cost advantages for UK industries benefitting from lower prices for raw materials and the energy they use; and 
- Fracking will lead to job creation in the UK. According to Gosden (2013), as many as 2880 wells could be drilled generating up to a fifth of the nations annual gas demand at peak and creating thousands of jobs.

\subsection{Theme 3: Challenge of reducing carbon emissions in the UK}

There was a consensus that the country's aggressive carbon emissions goals call for the U.K's power supply to be virtually carbon-free by 2030. Several participants emphasised that UK can achieve its 2030 emission reduction targets by replacing all coal power by gas generation. Shale gas extraction is considerably more energy intensive and therefore produces more carbon emissions per cubic meter (Green et al. 2012). According to PwC (2013), the use of fracking technology gives access to much greater fossil fuel reserves and is likely to increase total carbon in the atmosphere in the long term.

Fairley (2013) believes that if the UK cannot come up with an affordable supply of natural gas via hydrofracking of its shale deposits, it might have to restart mothballed coal-fired power plants to keep the lights on in future decades. The problem for the Government is that investment in carbon capture storage and nuclear is at an early phase. To a large extent that is a failure of the European Trading System, which was intended to render low-carbon technologies competitive with fossil fuels (Fairley 2013). As acknowledged by the participants, long-term demand of energy is rising, with the global population likely to rise as more people move out of poverty. Participants further stated that all sources of energy will be needed in the UK.

\subsection{Theme 4: Government support for communities and local authorities}

All the five government policy makers appeared to strongly suggest that:

- The Government and operators have agreed to engage with communities and local authorities early, and to provide community benefits in areas where shale is commercially extracted. As confirmed in the literature, these will include $£ 100,000$ for communities situated near each exploratory well, and 1 per cent revenues from every production site (Harris 2013); and

- Local authorities would be able to keep 100 per cent of business rates collected from shale gas sites. It is worth noting that this doubled the existing 50 per cent figure under the Government's business rate retention scheme which, according to a 
Government estimate, could be worth up to $£ 1.7$ million for a typical 12 well site (White et al. 2013).

Beebeejaun (2013) presents quite a different perspective on the subject. According to Beebeejaun (2013), the 'community argument' is potholed, as the case of the Marcellus Shale exemplifies. For instance, in New York State, where the moratorium stands, leases were signed in 2000 before the dash of shale gas, some as little as $\$ 3$ per acre and 12.5 per cent of royalties. Leases signed in the Pennsylvania state portion of the Marcellus site were a thousand times that of New York state landowners. Evidence shows, payments of 12.5 per cent of total revenues were vast compared to the 1 per cent being offered by the coalition government in the UK (Beebeejaun 2013). It has been suggested that the Government will be allowed to take about two-thirds of the revenue through taxes (Cartwright and Self 2013).

With regards to revenues through taxes, Cartwright and Self (2013) found that the tax system for fracking is likely to be similar to that for North Sea Oil and Gas, with the addition of specific incentives to encourage the sector in its early stages of development. According to Cartwright and Self (2013), the corporation tax will be charged at a higher rate of 30 per cent, and profit and loses will be subject to a "ring fence" to prevent any offset between shale gas losses and profits from other trades, or vice versa. However, it is likely that shale gas and oil profits will be set within a single ring fence, so that North Sea operators will be able to counterbalance shale gas losses against North Sea revenues. In addition, the Government will introduce a supplementary charge of 32 per cent of ring profits, with no deduction for financing costs. It is worth noting that, in the early phase of the field development, there will be loses incurred. The economic value of these losses will be preserved by a ring fence expenditure supplement, which adds 10 per cent to any unused expenditure (Cartwright and Self 2013). Results reported in this theme suggest that local communities in the UK will not be the main recipients of shale gas but will face the consequences of shale gas exploration on a regular basis.

There was general acceptance from all the participants that commercial fracking is not yet taking place. According to the five local community members $(B, C, F, G, H)$ interviewed, one of the main issues they raised is that their local government councils have demonstrated insufficient knowledge on fracking. Despite several incentives proposed by the Government, the growth of knowledge in relation to fracking is now directly challenging local council decisions. The participants believed that environmental costs and remediation of technological revolt will be borne by the UK Government and local communities. 
According to Beebejaun (2013), opponents of fracking have come up with important questions about who bear the risks of environmental threats and how these decisions are made democratically. Beebejaun (2013) argues that the focus on speculative financial benefits ignores these wider inferences. The dispute is far broader than a narrow focus on energy bills and encompasses longer-term implications for environmental sustainability, protection of the landscape and potential threats to water quality, environment and human health.

\section{Conclusions and recommendations}

As evidenced in this study, the UK Government's commitment to shale gas technology as part of a diverse energy mix is as strong as ever. The rising cost of oil, as well as the increasing scarcity of natural gas has improved the value of shale gas in the UK. There has been a slow push by the Government to enact some environmental regulation in order to keep up with the eagerness of the industry to introduce shale gas technology. As conclusively shown in this study, the process of fracking stimulates a cost-benefit analysis between the potentially massive economic benefit and the equally sizeable environmental and health problems. For instance, the practice has increased rapidly in the US (Armour 2014; Boudet et al. 2014; Martin et al. 2014; Smith and Ferguson 2013), and it seems that serious research into its side effects are only now beginning to catch up.

From a UK perspective, it is important that the process is carefully examined by the government and industry operators to determine its true cost and create a basis for regulation. Due to its environmental regulations, the UK is unquestionably an unattractive place to do business in fracking. The Government and industry do not enjoy consistently high levels of community support. The present study confirms that the Government is committed to ensuring that the nation maximises the opportunity that cost effective shale gas technology presents, not just investment, cheap energy bills and jobs but providing an energy mix that will underpin the UK long term economic prosperity.

The findings from this study suggest that the integration of shale gas technology will protect consumers against rising energy prices and ensure that government does not get exposed to long-term geopolitical risks. Given the current problems between US, European Union and Russia, and due to the fact that the UK buys domestic gas from other nations, it is looking increasingly likely that fracking will go ahead. The North Sea gas supplies are forecast to fall as well, it is therefore vital that the UK Government develops local gas reserves and avoid 
having to rely on a fluctuating external market in years to come. The Government should be prepared to diversify future sources of natural gas supplies to Europe. Secondly, the Government needs to boost energy investment in gas interconnections and terminals in Europe and widen indigenous European energy supplies for nations wishing to build up their own energy resources.

The time is rife for a complete overhaul of UK energy models and environmental regulations. With regards to UK environmental regulations, a number of recommendations are already being adopted by operators, and it is worth pointing out that current regulations are strict enough to protect local communities and the environment. The present study corroborates the position that environmental, health and safety risks can be managed effectively provided operational best practices are implemented and monitored by the Health and Safety Executive, Department of Energy, Climate Change, and the Mineral Planning Authorities. As shown in this study, the UK has a very strong regulatory regime compared to US and so environmental, health and safety risks will be very well managed and unlikely to escalate into the crisis being envisioned.

There is therefore a need for the UK Government to invest in shale gas technology. As evidenced in this study, every credible scenario indicates further growth in demand for oil and gas over the next 20 years and providing around 70 per cent of UK energy in 2020 (OGER 2012). Although energy efficiency has an important role to play, unparalleled levels of reserves will be required over the next two decades and the energy sector will have to carefully balance and optimise its indigenous oil and gas resources. There are no simple or inexpensive solutions, the challenge is to capitalise on existing strengths and deliver actions that ensure energy efficiency and long-term energy security. As evidenced from the findings, there may still be limited lack understanding about fracking. Therefore, effective risk communication efforts can help increase the awareness of these impacts. Energy stakeholders in favour or against fracking can pay more attention to informing and educating the wider public to change their perception on contemporary energy developments (Haut et al. 2010). An encouraging area for future effective risk communication will be by expanding people's thinking of fracking beyond the process of merely extracting oil and gas to a comprehensive awareness of the diverse benefits associated with the various stages of unconventional oil/gas development overtime. Various media formats can play potentially important roles through documentaries. If effectively managed, fracking can become the foundation for UK's nation's energy future. The findings of this study have a number of important implications: 
- The Government should strengthen Health and Safety Executive, Department of Energy, Climate Change and the Mineral Planning Authorities, including providing additional resources;

- The Government should also fortify the system of well inspections to ensure robust monitoring of methane in groundwater, and that well designs are considered from both environmental perspective and health and safety perspective. Data collection on methane emissions should be mandatory and not voluntary;

- As the use of fracking is likely to increase, so will environmental concerns over dangers of pollution and groundwater contamination. It will therefore be imperative for the Government to mandate and enforce Environmental Risk Assessments throughout for all gas operations in the UK;

- So far, the ability for local communities to participate in the decision making process has been limited. Moving forward, primary stakeholders should make every effort to incorporate local communities in the decision making process.

\section{References}

Accenture, (2012). Developing strategies for the effective delivery of capital projects:

Accenture global survey of the energy industry. available from:

$<$ http://www.accenture.com/us-en/Pages/insight-capital-projects-global-survey-energyindustry.aspx> (cited $16^{\text {th }}$ March 2014).

Aleklett, K., Hook, M., Jakobsson, K., Lardelli, M., Snowden, S. and Soderbergh, B. (2010). The peak of the oil age-analysing the world oil production reference scenario in World Energy Outlook 2008, Journal of Energy Policy, Vol. 38 No. 3, pp.1398-1414.

Armour, N.J., (2014). Key questions, approaches, and challenges to energy today. Catalysis Today", (in press). available from:

<http://www.sciencedirect.com/science/article/pii/S0920586113006950> (cited $6^{\text {th }}$ March 2014).

Asche, F., Oglend, A. and Osmundsen, P. (2012). Gas versus oil prices the impact of shale gas, Journal of Energy Policy, Vol. 47, pp.117-124.

American Petroleum Institute, (2010). Hydraulic fracturing. Retrieved from $<$ http://www.api.org/policy/

exploration/hydraulicfracturing/upload/HYDRAULIC_FRACTURING_PRIMER.pdf> (cited $15^{\text {th }}$ March 2014). 
BBC, (2014). Davos: Fracking to boost UK economy. available from:

$<$ http://www.bbc.co.uk/news/uk-politics-25868997> (cited 15 ${ }^{\text {th }}$ March 2014).

Braun, V. and Clarke, V. (2006). Using thematic analysis in psychology, Journal of Qualitative Research in Psychology, Vol. 3 No.2, pp.77-101.

Beebeejaun, Y., (2013). The politics of fracking: A public policy dilemma?. Political Studies Association. available from: <http://www.psa.ac.uk/insight-plus/politics-fracking-public-policydilemma> (cited $17^{\text {th }}$ March 2014).

Broderick, J., Anderson, K., Wood, R., Gilbert, P. and Sharmina, M. (2013). Shale gas: an updated assessment of environmental and climate change impacts. available from: <http://www.tyndall.ac.uk/sites/default/files/coop shale gas report update v3.10.pdf> (cited $18^{\text {th }}$ February 2014).

Brooks, M. (2013). Frack to the Future, New Scientist. available from:

$<$ http://www.newscientist.com/article/dn23968-frack-on-or-frack-off-can-shale-gas-save-theplanet.html> (cited 1 $7^{\text {th }}$ February 2013).

Brown, S. and Krupnick, A. J. (2010). Abundant shale gas resources: Long term implications for U.S. natural gas markets. RFF Discussion Paper 10-41. Washington, DC: Resources for the Future.

Boudet, H., Clarke, C., Bugden, D., Maibach, E., Roser-Renouf, C. and Leiserowitz, A. (2014). Fracking controversy and communication: Using national survey data to understand public perceptions of hydraulic fracturing, Journal of Energy Policy, Vol. 65, pp. 57-67.

Boyatzis, R.E. (1998). Transforming qualitative information: Thematic analysis and code development, Sage Publication Limited, London.

Cartwright, T. and Self, H. (2013). Shale gas toolkit, Tax and incentives for the shale gas industry, Part 2. available from:

$<$ http://www.pinsentmasons.com/en/media/publications/shale-gas-and-fracking-in-the-uk/> (cited $16^{\text {th }}$ March 2014).

Davies, C. (2012). The politics of "fracking": Regulating natural gas drilling practices in Colorado and Texas. Review of Policy Research, Vol. 29 No.2, pp. 177-191.

Davies, R. (2013). Induced seismicity and the hydraulic fracturing of low permeability sedimentary Rock. Durham University. available from:

$<$ https://www.dur.ac.uk/news/newsitem/?itemno=17347> (cited 19 ${ }^{\text {th }}$ March 2014).

DECC. (2012). Energy security strategy. Department of Energy and Climate Change, November 2012. Available from: <https://www.gov.uk/government/policies/maintaining-ukenergy-security--2> (15 ${ }^{\text {th }}$ March 2014).

DECC. (2103). Onshore oil and gas exploration in the UK: regulation and best practice.

Department of Energy and Climate Change (England), December 2013.

DECC. (2103). Onshore oil and gas exploration in the UK: regulation and best practice.

Department of Energy and Climate Change (Wales), December 2013. 
EIA. (2011). World shale gas resources: an initial assessment of 14 regions outside the USA", US Energy Information Administration, Department of Energy: Washington DC. available from: <http://www.eia.gov/analysis/studies/worldshalegas/ pdf/fullreport.pdf> (cited $12^{\text {th }}$ February 2014).

Erdos, P. (2012). Have oil and gas prices got separated?, Journal of Energy Policy, Vol. 49, pp. 707-718.

Ernst and Young. (2012). Powering the UK: The role of the power and gas sector in the wider economy.

Fairley, P. (2013). Desperate U.K. turns to shale gas. MIT Review Technology. available from: <http://www.technologyreview.com/news/518936/desperate-uk-turns-to-shale-gas/> (cited $19^{\text {th }}$ February 2014).

Gorsden, E. (2013). Half of Britain to be offered for shale gas drilling as fracking areas face 50 trucks passing each day. The Telegraph Newspaper. available from:

$<$ http://www.telegraph.co.uk/earth/energy/fracking/10523069/Half-of-Britain-to-be-offeredfor-shale-gas-drilling-as-fracking-areas-face-50-trucks-passing-each-day.html> (cited $17^{\text {th }}$ March 2014).

Grbich, C. (2007). Qualitative data analysis: An introduction, Sage Publications Limited, London.

Harris, J. (2013). Fracking the nation: the dash for gas beneath rural Britain. Guardian Newspaper, Friday $28^{\text {th }}$ June. available from:

<http://www.guardian.co.uk/environment/2013/jun/28/fracking-dash-gas-rural-england> (cited $17^{\text {th }}$ July 2013 ).

Harvey, F. (2013). UK shale gas viability check will take five years, says Cuadrilla boss. Guardian Newspaper, available from:

$<$ http://www.theguardian.com/environment/2014/jan/31/uk-shale-gas-fracking-cuadrilla> (cited $18^{\text {th }}$ March 2014).

Haut, R.C., Williams, T. ,Burnett, D.,Theodori,G., (2010). Balancing environmental tradeoffs, societal issues, and energy production. Gulf Coast Association of Geological Societies Transactions. 60, pp. 739-748.

HoC. (2011). Shale gas: fifth report of session 2010-12. Volume I, House of Commons: London. available from: <http://www.scribd.com/doc/59299635/House-of-Commons-ShaleGas> (cited $13^{\text {th }}$ February 2014).

Hunter, D. (2013). BBC news channel weighs up pros and cons of fracking with Schneider electric. available from:

$<$ http://www.mcenergygroup.co.uk/media centre/news/bbc news channel weighs up pros cons of fracking with schneider electric/> (cited $21^{\text {st }}$ October 2013). 
International Energy Agency. (2009). World energy outlook, International Energy Agency. available from: <http://www.worldenergyoutlook.org/media/weowebsite/2009/WEO2009.pdf> (cited $12^{\text {th }}$ February 2014).

International Energy Agency. (2011). Are we entering a golden age of gas?. Special Report World Energy Outlook 2011. available from:

$<$ http://www.worldenergyoutlook.org/media/weowebsite/2011/WEO2011 GoldenAgeofGasR eport.pdf> (cited 11 ${ }^{\text {th }}$ February 2014).

International Energy Agency. (2012). Golden rules of a golden age of gas. World Energy Outlook. Special Report on Unconventional Gas. International Energy Agency. Available from:http://www.worldenergyoutlook.org/media/weowebsite/2012/goldenrules/weo2012 gold enrulesreport.pdf (cited 15 January 2015).

Institute of Directors. (2013). Infrastructure for Business: Getting shale gas working. Institute of Directors. 22 May 2013.

IHS Global Insight (2010). Fueling North America's energy future. An IHS CERA Special Report.

Kjarstad, J. and Johnsson, F. (2009). Resources and future supply of oil, Journal of Energy Policy, Vol. 37, No.2, pp. 441-464.

McGlade, C., Speirs, J. and Sorrell, S. (2012). A review of regional and global estimates of unconventional gas resources. A report to the Energy Security Unit of the Joint Research Centre of the European commission", UKERC. available from: www.ukerc.ac.uk/support/tikidownload file.php?fileld=2672> (cited $11^{\text {th }}$ February 2014).

Mckenna, G. M., Wilczynski, H. and VandeSchee, D. (2006). Capital project execution in the oil and gas industry: Increased challenges, increased opportunities.

Melo-Martín, I., Jake Hays, J. and Finkel, M. (2014). The role of ethics in shale policies, Science of the Total Environment, pp.1114-1119.

Milosevic, Z., and Markovic, S. (2012). The changing geopolitics of energy, Journal of the Geographical Institute, 62 (1), pp. 125-134.

Mohr, S.H. and Evans, G.M. (2010). Long term prediction of unconventional oil production. Journal of Energy Policy, 38 (1), pp. 256-276.

Nachmias, F.C. and Nachmias, D. (1996). Research methods in the social sciences, $5^{\text {th }}$ Edition, UK: Hodder Education.

Nakhle, C. (2007). Do high oil prices justify an increase in taxation in a mature oil province? The case of the UK continental shelf, Journal of Energy Policy, Vol. 35 No. 8, pp. 4305-4318. 
Ochieng, E.G., Melaine, Y., Potts, S.J., Zuofa, T., Egbu, C.O., Price, A.D.F. and Ruan, X. (2014). Future for offshore wind energy in the United Kingdom: The way forward, Journal of Renewable and Sustainable Energy Reviews, 29, pp. 655-666.

OGER. (2009). Oil and Gas UK the voice of the Offshore Industry (2011)." available from: $<$ www.oilandgasuk.co.uk $>$ (cited $21^{\text {st }}$ November 2013).

OGER. (2010). Oil and Gas UK the voice of the Offshore Industry (2010). Oil and Gas UK Activity Survey Report. available from: <www.oilandgasuk.co.uk> (cited $11^{\text {th }}$ November 2012).

OGER. (2012). Oil and Gas UK the voice of the Offshore Industry (2012). Oil and Gas Economic Report. available from: <www.oilandgasuk.co.uk> (cited $11^{\text {th }}$ November 2012).

OGER. (2013). Oil and Gas UK the voice of the Offshore Industry (2013). Available from: $<$ www.oilandgasuk.co.uk> (cited $18^{\text {th }}$ February 2013).

Pasty, R., Fell, M., Smith, L. and Keep, M. (2013). Shale gas and Fracking-Commons Library Standard Note. available from: <http://www.parliament.uk/briefing-papers/SN06073> (cited $18^{\text {th }}$ September 2013).

Pearce, F. (2013). Fracking: the monster we greens must embrace. Guardian Newspaper, ,available from: < http://www.theguardian.com/commentisfree/2013/mar/15/fracking-monstergreens-must-embrace $>$ (cited $15^{\text {th }}$ March 2013).

PwC. (2013). Shale oil: The next energy revolution. available from:

$<$ http://www.pwc.se/sv SE/se/energi/assets/shale-oil-the-next-energy-revolution.pdf> (cited $15^{\text {th }}$ March 2014),

Richards, P., Fell, M., Smith, L. and Keep, M. (2013). Shale gas and fracking, science and environment Section. House of Commons Library, UK, available from:

$<$ http://www.parliament.uk/briefing-papers/SN06073> (cited 15 ${ }^{\text {th }}$ July 2013).

Ruddiman, B., Rice, P., Griffiths, R., Ford, R., Owen, R. and Pocock, M. (2013). Shale gas and fracking toolkit, Planning Part 3. Pinsent Masons. available from:

$<$ http://www.pinsentmasons.com/en/media/publications/shale-gas-and-fracking-in-the-uk/> (cited $16^{\text {th }}$ March 2014).

Smith, M. and Ferguson, D.P. (2013). Fracking democracy: Issue management and locus of policy decision-making in the Marcellus Shale gas drilling debate. Public Relations Review, 39, 377-386.

The Royal Society. (2012). Shale gas extraction in the UK: A review of hydraulic fracturing. available from: <http://royalsociety.org/policy/projects/shale-gas-extraction/report/> (cited $11^{\text {th }}$ February 2014).

Thomson Reuters. (2014). Hydraulic fracturing-how it works. available from: http://blog.thomsonreuters.com/index.php/tag/fracking/> (cited 24 $4^{\text {th }}$ March 2014).

White, E., Fell, M., Smith, L. and Keep, M. (2014). Shale gas and fracking, science and environment section. House of Commons Library, UK. available from: 
$<$ http://www.parliament.uk/business/publications/research/briefing-papers/SN06073/shalegas-and-fracking $>$, (cited $15^{\text {th }}$ February 2014).

UNEP, (2011). Athabasca oil sands, require massive investments and energy and produce massive amounts of oil and CO2-Alberta, Canada. Global Environment Alert Service. United Nations Environment Programme, January 2011, 54, pp. 1-5.

U.S. Energy Information Administration. (2011). Review of emerging resources: U.S. shale gas and shale oil plays. available from

$<$ http://www.eia.doe.gov/energy in brief/about shale gas.cfm > (cited $11^{\text {th }}$ February 2014). 